\title{
TWO POLYGYNE OVERWINTERED NESTS OF VESPULA VULGARIS FROM CALIFORNIA
}

\author{
By Francis L. W. Ratnieks \& Donald G. Miller \\ Department of Entomology \\ University of California \\ Berkeley, CA 94720, USA
}

Yellowjacket wasps, Vespula and Dolichovespula, form a monophyletic group in the family Vespidae (Carpenter, 1991). All species are eusocial or are social parasites of other yellowjackets (Greene, 1991). The colony life cycle is typically annual, with nest founding by lone queens in springtime. Reproductives are produced sometime from summer to early winter, depending on the species and location, and the colony then dies out (Spradbery, 1973; Akre et al., 1980; Greene, 1991). An interesting modification of this typical cycle is the occasional overwintering of a colony, giving rise to biennial or perennial colonies which usually contain multiple reproductive queens (Edwards, 1980; Ross and Matthews, 1982; Ross and Visscher, 1983; Greene, 1991; Spradbery, 1991). These polygyne colonies only occur in species that produce reproductives late in the year ("long-cycle" species), as in the $V$. vulgaris and V. squamosa groups (Ross and Matthews, 1982). Short cycle species, Dolichovespula and V. rufa group, are not reported to give rise to polygyne colonies (Ross and Matthews, 1982). Polygyne colonies are only found in areas with mild winters, such as North Africa, Florida, California, Australia, and New Zealand (Edwards, 1980), probably because insect prey is continuously available only in such areas. Gambino (1986) documented successful winter insect-prey capture by a $V$. vulgaris colony in California.

This study describes the nest contents of two overwintering nests of $V$. vulgaris from California, where it is a native species. This is the first detailed information on this colony type in $V$. vulgaris. Previous studies of overwintered nests are Gambino (1986), who studied prey collection, and Duncan (1939), who provided a

Manuscript received 30 April 1992 
brief description of nest contents. Both studies were done in California.

\section{Methods}

Nest sites and collection

Two overwintering nests of $V$. vulgaris were reported to the University of California at Berkeley Pest Management Service. One nest (colony 1) was located on the main campus, in the garden of the University Chancellor, and was collected on 28 January 1992. The other (colony 2) was located ca. $3 \mathrm{~km}$ north in the garden of the University President and was collected on 14 February 1992. Both were ground nests under redwood trees. The nests were covered by $2-5 \mathrm{~cm}$ of soil, and $5-10 \mathrm{~cm}$ of redwood needles. These nest locations are typical of V. vulgaris (Akre et al., 1980).

Nests were dug up early in the morning before appreciable foraging began. Wasps were anaesthetized by pouring powdered dry ice into the entrance tube. We estimate that greater than $95 \%$ of all adult wasps and all the brood were collected by this method.

\section{Analysis of nest contents}

Each comb was measured for length and breadth, and comb area was calculated based on the formula for the area of an ellipse. The combined diameter of 10 adjacent cells was measured to estimate cell diameter. The number of cells in the comb was estimated by dividing comb area by cell area. In some combs cells of two sizes were found. Two combs were approximately equally divided into a patch of small cells and a patch of large cells. For these, the areas and diameters were measured for each patch separately. In each comb of colony 2 we counted the number of eggs per cell in ten cells, for cells located in the center of the comb, and for cells located around the periphery of the comb. The peripheral cells were typically newly constructed cells, whereas the central cells were being reused, as evidenced by the accumulated meconia.

To determine the sex and caste of the brood we removed the contents of cells containing capped brood (i.e., cells covered by cocoon silk). Capped brood in the pupal stage were easily recognized as male, worker, or queen based on their size and antennal length. Combs containing large numbers of capped brood were broken in half, and one half was uncapped. An estimate of the total 
number of pupae of each caste was obtained by first counting the total number of capped brood cells in the whole comb and in the half to be uncapped. Adult wasps were counted individually. Queens and workers were recognized by size.

\section{Reproductive status of queens and workers}

We classified the reproductive status of both queens and workers based on the length of the longest oocyte in either ovary. Females with no oocyte greater than $1 \mathrm{~mm}$ in length were classified as undeveloped; those with an oocyte greater than this were classified as developed. Fully developed eggs, obtained from the combs, measured $2.1 \mathrm{~mm}$ (Colony 1; S.D. $=0.06, \mathrm{n}=6$ ) and $1.9 \mathrm{~mm}$ (Colony 2; S.D. $=0.10, \mathrm{n}=20$ ).

As a further measure of reproductive status we dissected the spermatheca from some queens. Individual sperm could easily be seen by squashing the spermatheca under a coverslip and examining under high power. In some queens the number of sperm stored in the spermatheca was estimated by crushing the spermatheca in $100 \mu \mathrm{l}$ of saline, and counting in a hemacytometer slide using phase contrast.

\section{RESULTS}

\section{Nest structure and contents}

Nests were similar, with 10 and 11 combs, 2731 and 2235 adults, and 2575 and 2678 pupae respectively in Colonies 1 and 2 (Table 1 ). Both nests contained large numbers of pupal and adult males, workers, and queens. Workers formed the majority of adults, $71 \%$ and $62 \%$, but only $40 \%$ and $36 \%$ of the pupae. Except for the uppermost comb in Colony 1 , all combs were being used for brood rearing and contained eggs and larvae.

Most combs contained cells of a single size. However combs 5 and 8 of Colony 2 contained $35 \%$ and $57 \%$ of large cells respectively. Comb 7 contained a $2 \mathrm{~cm} \times 3 \mathrm{~cm}$ patch of small diameter cells. In colony 1 all combs contained cells of one size except for comb 6 which had a few large cells round the edge of a comb of small cells.

Cells centrally located in the combs typically contained multiple eggs, but few cells on the edge of combs contained more than one egg (Table 1). Eggs were all laid by queens (see below) and were 


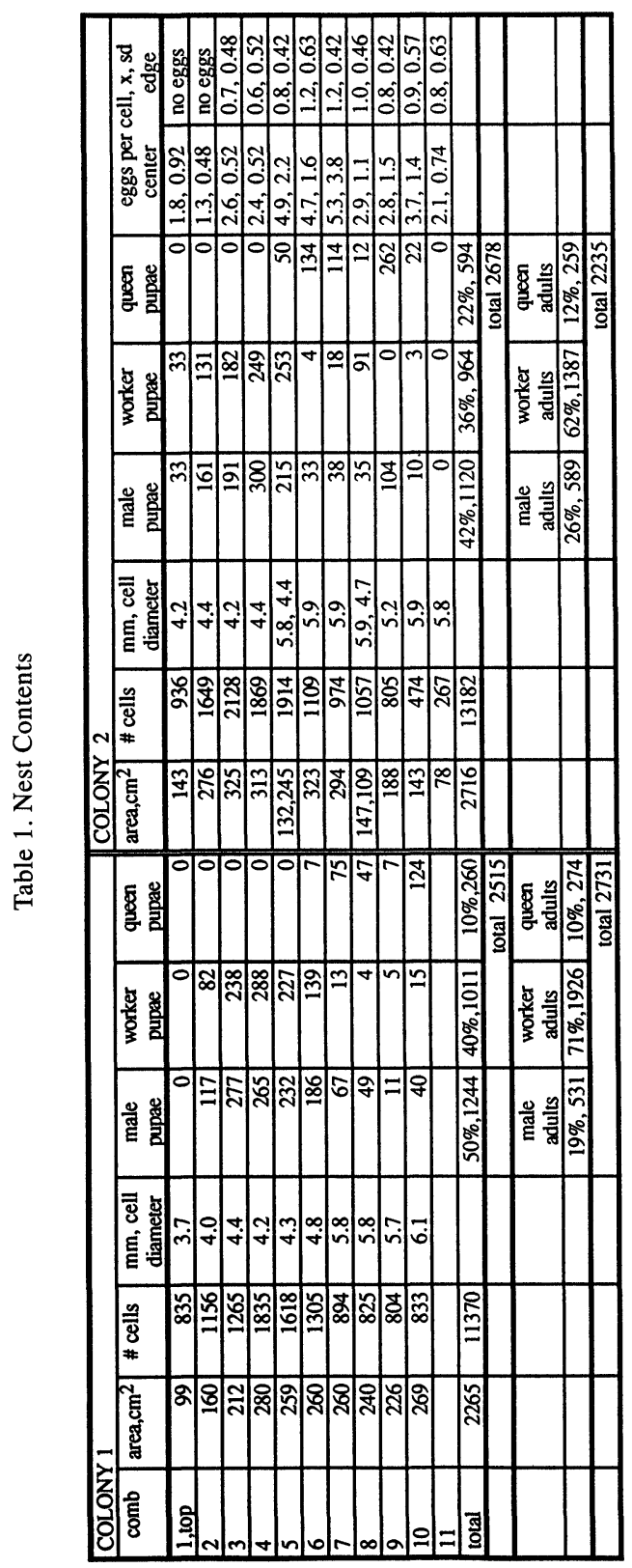


on the bottom surface of the cell, not on the sides as in perennial V. maculifrons (Ross and Visscher, 1983).

\section{Reproductive status of workers and queens}

Two hundred workers from each colony were dissected. None had developed ovaries. In yellowjacket nests the founder queen (i.e., the original mother) can usually be recognized based on worn appearance and enlarged abdomen. Although some of the queens in both nests had slight wear to the the wing tips and abdominal discoloration, none were highly worn or extremely physogastric. As a result, we think it unlikely that either colony contained the original founder queen. Queen ovary development and insemination are shown in Table 2. There was a highly significant association of insemination with ovary development $\left(\mathrm{chi}^{2}\right.$ test, $\mathrm{p}<0.001$ in both cases), as previously reported in polygyne $V$. squamosa (Ross and Matthews, 1982). In Colony 2 the longest oocyte lengths of uninseminated queens with developed ovaries were slightly lower, 1.85 $\mathrm{mm},(\mathrm{S} . \mathrm{D} .=0.22, \mathrm{n}=9)$ than that of inseminated queens with developed ovaries, $1.95 \mathrm{~mm},($ S.D. $=0.18, \mathrm{n}=29)$. This difference is not significant (two sample t-test; $\mathrm{p}>0.05$ ).

Sperm counts were made from 20 inseminated queens from each colony (Figure 1). There was considerable variance in sperm numbers. In addition, queens from colony 1 had a lower mean number of sperm than those from colony 2 , although this difference is not significant (two sample t-test; $p>0.05$ ). Because queens in other Vespula species mate with multiple males (Ross, 1986), it is

Table 2. Ovary development and insemination of queens.

\begin{tabular}{lccc}
\hline colony & developed ovaries $(<1 \mathrm{~mm})$ & undeveloped ovaries $(>1 \mathrm{~mm})$ \\
\hline 1 & $30(42 \%)$ & $41(58 \%)$ \\
$28(41 \%)$ & $54(59 \%)$
\end{tabular}




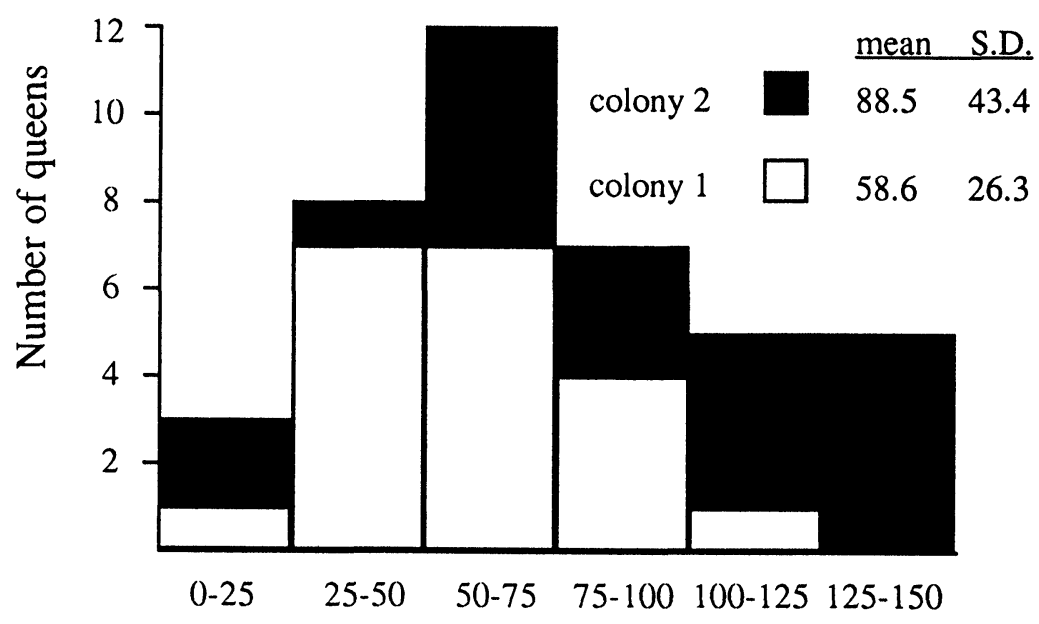

Number of sperm, thousands

Figure 1. Sperm counts for V. vulgaris

possible that the low sperm counts of some queens may not represent their final complement of sperm.

\section{Discussion}

The large numbers and proportions of workers, both adult and pupae, in the nests suggest that both colonies were thriving and would have survived indefinitely had they not been collected. Despite the apparent viability of these nests, they are nevertheless relatively rare. Over approximately the last decade, the campus Pest Management Service has only encountered three such nests, these two plus one other V. vulgaris, while about 100 annual $V$. vulgaris nests have been discovered (A. Slater, personal communication).

The adult populations and numbers of cells in the two studied nests were in the mid-range, in comparison to other Vespula species (Spradbery, 1991) and were not appreciably greater than can be found in annual nests at the end of the year (Akre et al., 1980). Because both nests were collected early in their second 
year, their final populations and sizes might have been much greater. Both nests were constructing new combs at the time of collection. The V. vulgaris nest mentioned by Duncan (1939) contained approximately four gallons of adults (ca. 60,000, Akre et al. 1980), and were mostly workers. Overwintered nests of very high population also occur in other Vespula (Spradbery, 1991).

The absence of worker reproduction in these nests is interesting. Worker reproduction in first-year monogyne nests does not occur in two V. vulgaris group species studied by Ross (1986). However, Ross and Visscher (1983) found considerable worker ovary-development in an overwintered polygyne colony of $V$. maculifrons.

Based on the total number of queens and the proportion of these with developed ovaries, approximately 100 queens in each nest were egg-laying, of which the majority were inseminated. Duncan (1939) reported 22 functional queens in the V. vulgaris colony he studied, which were recognized by their frayed wing tips and backs worn free of setae. Because dissections were not made, it is possible that this number is an underestimate of the actual number of egg-layers. The number of reproductive queens in overwintered Vespula nests ranges from one to 400 (Spradbery, 1991).

\section{SUMMARY}

Two overwintered nests of Vespula vulgaris were collected in California. The nests were similar, and contained: adult males: 531, 589; adult workers: 1926, 1387; adult queens 274, 259; \% adult workers with developed ovaries: 0,0 ; $\%$ adult queens with developed ovaries: 42, 41; pupal males: 1244, 1120; pupal workers: 1011, 964; pupal queens: 260, 594; combs 10, 11 .

\section{ACKNOWLEDGEMENTS}

Arthur Slater of UC Berkeley Pest Management Service told us about the nests and helped collect them. Kibi Schultz helped in the laboratory. Funding was provided by NSF grant BNS 9009197 to W. M. Getz.

\section{Literature Cited}

Akre, R. D., A. Greene, J. F. McDonald, P. J. Landolt and H. J. Davis

1980. The yellowjackets of America north of Mexico. United States Department of Agriculture. Handbook no. 552. 
CARPENTER, J.

1991. Phylogenetic relationships and the origin of social behavior in the Vespidae. Pages 1-32 in: Ross, K. G. and R. W. Matthews (eds). The social biology of wasps. Cornell University Press, Ithaca, NY.

DunCAN, C. D.

1939. A contribution to the biology of North American Vespine Wasps. Stanford University Press, University Series, Biological Sciences: Vol. 8, number 1 .

EDWARDS, R.

1980. Social wasps. Rentokil Ltd., East Grinstead, UK.

GAMBINO, P.

1986. Winter prey collection at a perennial colony of Paravespula vulgaris

GREENE, A.
(L.) (Hymenoptera: Vespidae). Psyche 93: 331-340.

1991. Dolichovespula and Vespula. Pages 263-308 in: Ross, K. G. and R. W. Matthews (eds). The social biology of wasps. Cornell University Press, Ithaca, NY.

Ross, K. G.

1986. Kin selection and the problem of sperm utilization in social insects. Nature 323: 798-800.

Ross, K. G. AND R. W. MatTHEWS

1982. Two polygynous overwintered Vespula squamosa colonies from the southeastern U.S. (Hymenoptera: Vespidae). Florida Entomol. 65: 176-184.

Ross, K. G. AND Visscher, P. K.

1983. Reproductive plasticity in yellowjacket wasps: a polygynous, perennial colony of Vespula maculifrons. Psyche 90: 179-191.

SPRADBERY, J. P.

1973. Wasps. Sidgwick and Jackson, London.

1991. Evolution of queen number and queen control. Pages 336-388 in: Ross, K. G. and R. W. Matthews (eds). The social biology of wasps. Cornell University Press, Ithaca, NY. 

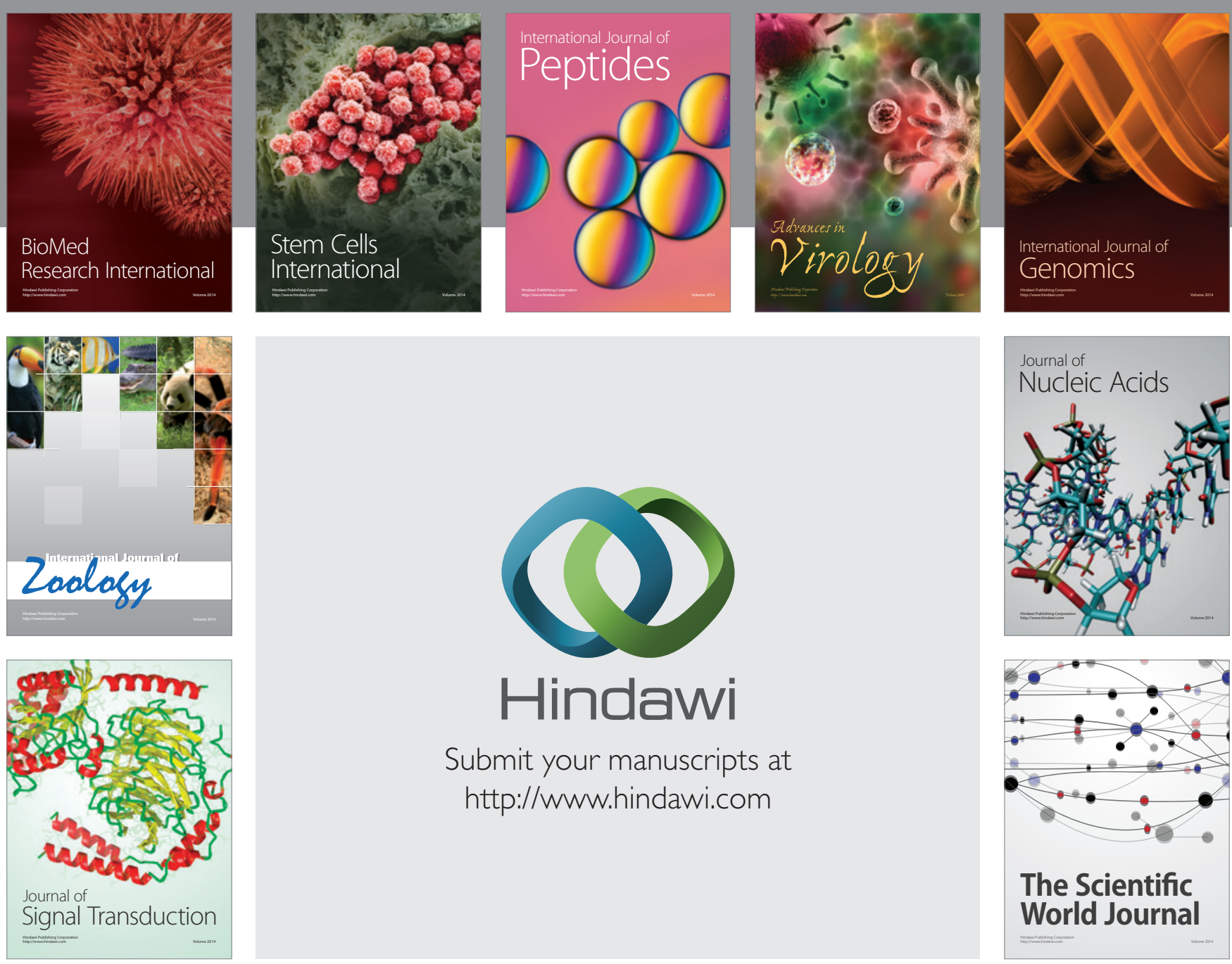

Submit your manuscripts at

http://www.hindawi.com
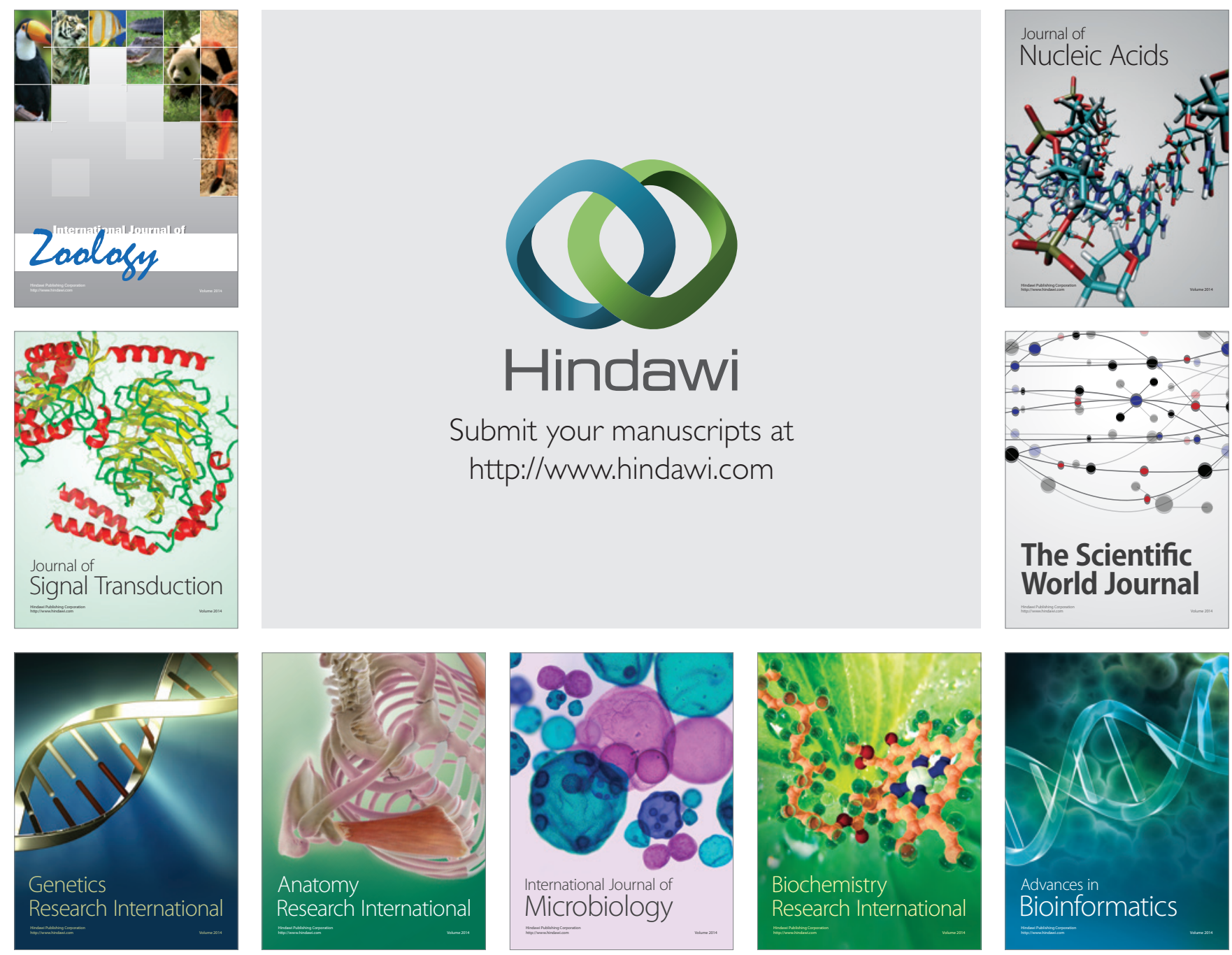

The Scientific World Journal
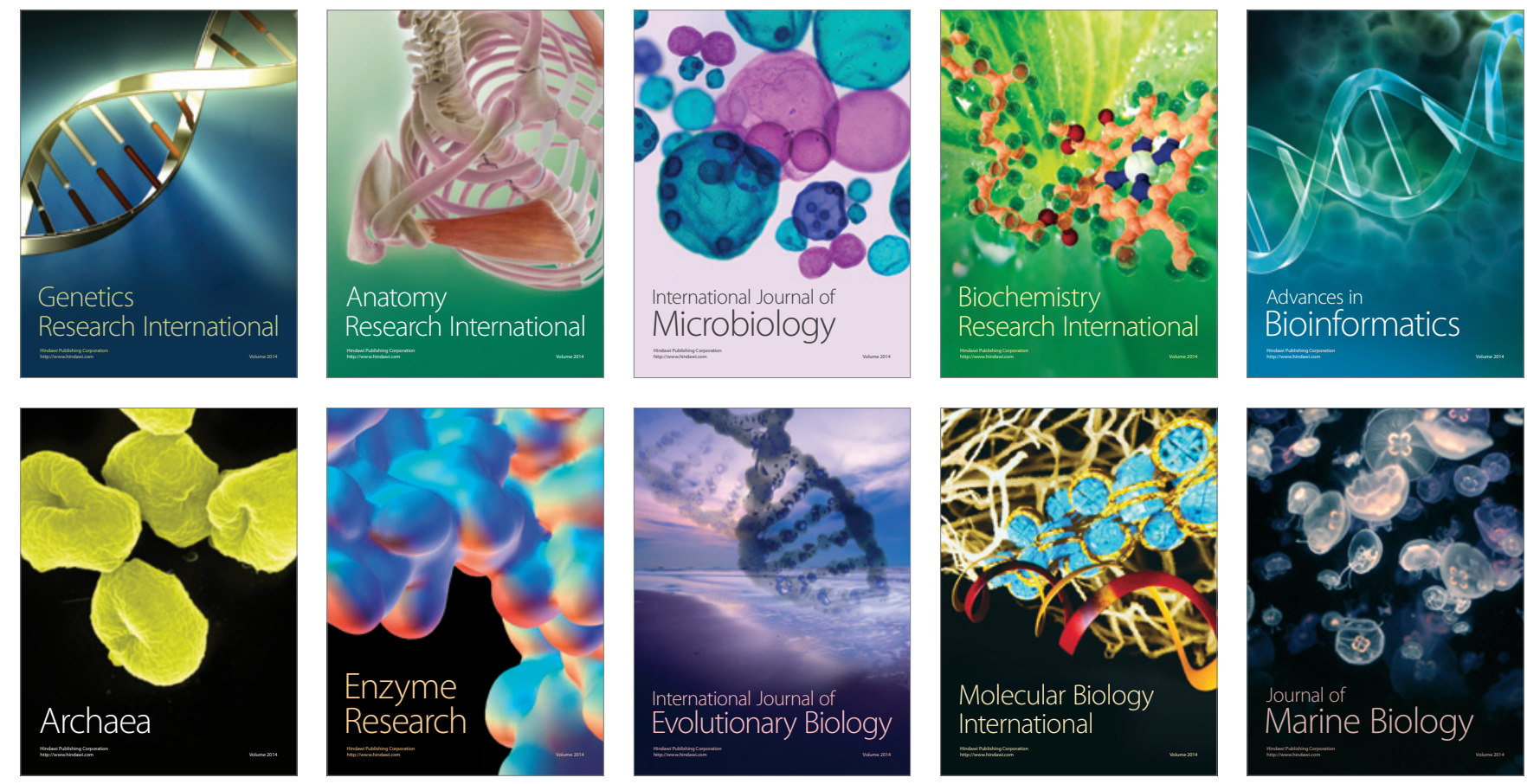